\title{
Heparin-binding peptide as a novel affinity tag for purification of recombinant proteins
}

Jacqueline Morris ${ }^{1}$, Srinivas Jayanthi ${ }^{1}$, Rebekah Langston ${ }^{1}$, Anna Daily ${ }^{1}$, Alicia Kight ${ }^{2}$, David S. $\mathrm{McNabb}^{2}$, Ralph Henry ${ }^{2}$, and Thallapuranam Krishnaswamy Suresh Kumar ${ }^{1 *}$.

1.Department of Chemistry and Biochemistry and 2. Department of Biological Sciences, University of Arkansas, Fayetteville, AR-72701, USA.

* To whom all correspondence should be addressed.

Correspondence author: TKSK. Email: sthalla@uark.edu; Tel - 479-575-5646; Fax - 479-5754049 


\begin{abstract}
Purification of recombinant proteins constitutes a significant part of the downstream processing in biopharmaceutical industries. Major costs involved in the production of biotherapeutics mainly depend on the number of purification steps used during the downstream process. Affinity chromatography is a widely used method for the purification of recombinant proteins expressed in different expression host platforms. Recombinant protein purification is achieved by fusing appropriate affinity tags to either $\mathrm{N}$ - or $\mathrm{C}$ - terminus of the target recombinant proteins. Currently available protein/peptide affinity tags have proved quite useful in the purification of recombinant proteins. However, these affinity tags suffer from specific limitations in their use under different conditions of purification. In this study, we have designed a novel 34-amino acid heparin-binding affinity tag (HB-tag) for the purification of recombinant proteins expressed in Escherichia coli (E. coli) cells. HB-tag fused recombinant proteins were overexpressed in E. coli in high yields. A one-step heparin-Sepharose-based affinity chromatography protocol was developed to purify HB-fused recombinant proteins to homogeneity using a simple sodium chloride step gradient elution. The HB-tag has also been shown to facilitate the purification of target recombinant proteins from their $8 \mathrm{M}$ urea denatured state(s). The HB-tag has been demonstrated to be successfully released from the fusion protein by an appropriate protease treatment to obtain the recombinant target protein(s) in high yields. Results of the two-dimensional NMR spectroscopy experiments indicate that the purified recombinant target protein(s) exist in the native conformation. Polyclonal antibodies raised against the HB-peptide sequence, exhibited high binding specificity and sensitivity to the HBfused recombinant proteins ( 10 nanograms) in different crude cell extracts obtained from diverse expression hosts. In our opinion, the HB-tag provides a cost-effective, rapid, and reliable avenue for the purification of recombinant proteins in heterologous hosts.
\end{abstract}

\title{
Keywords
}

Heparin, affinity tag, single-step, recombinant proteins and protein purification.

\section{Abbreviations}

HB - Heparin-binding; GST - glutathione-S-transferase; GSH - reduced glutathione; IPTG isopropyl thiogalactopyranoside; PMSF - phenyl methyl sulfonyl fluoride. 


\section{Introduction}

Recombinant proteins have gained major interest in the world of pharmaceuticals and therapeutics. Commercial applications of recombinant proteins include therapeutics, diagnostic tools, drug design, and instruments in proteomics [1,2]. The advent of recombinant DNA technology has facilitated the overexpression of target proteins in heterologous host cells and has revolutionized the field of protein biotechnology. Tandem development of affinity chromatography contributed to the rapid and efficient purification of recombinant proteins expressed in different host cells with much larger yields per se [3-5]. Typically, purification by affinity chromatography requires an affinity tag fused to the recombinant protein of interest [6]. In general, affinity tags used for protein purification are expected to possess the following properties: (a) high binding specificity to a resin coupled to one of the metal/substrate/protein affinity partner(s) but not limited to; (b) versatility to be fused with a wide range of target recombinant proteins; (c) non-interference in the folding of the target recombinant protein to retain its biological active conformation; and (d) amenability for selective and easy release from the target recombinant protein either by chemical or enzymatic cleavage methods. The most commonly employed affinity tags include polyhistidine (His-tag), glutathione-S-transferase (GST), maltose-binding protein (MBP), thioredoxin, and several others $[4,7]$. The currently available affinity tags have specific limitations in their use due to: 1 . Incompatibility with the conditions at which the recombinant target protein is stable and biologically active; 2 .

Degradation/aggregation of the affinity tag; 3 . Instability under denaturing conditions; 4 . Costeffectiveness of the overall purification process involving the affinity tag. Because of the various shortcomings of the existing affinity tags, there is a strong need for the development of a novel affinity tag that avoids most of the drawbacks. Recently, peptides have shown promise as purification affinity tags in that they are not only more chemically stable than large protein tags but also exhibit lower toxicity to the host cells [8].

Heparin, the most negatively charged poly-sulfated polyanionic member of the glycosaminoglycans, is mainly found on the surface of the cells and in the extracellular matrix region. It plays an important role in different key cellular processes. Several proteins are known to have strong heparin-binding properties [9-14]. Critical analysis of heparin-binding pockets in these proteins revealed a specific distribution of positively charged amino acid residues, which are primarily involved in electrostatic interaction with the negatively charged heparin. Such electrostatic interactions have been exploited to purify several positively charged proteins using cation exchange chromatography $[15,16]$. Studies performed by Cardin and Weintraub have shown that heparin-binding proteins (HBPs) contain consensus sequences or strings known as heparin-binding motifs that are responsible for their interaction specifically with heparin [17]. Some of the common putative heparin-binding segments were XBBXBX, $X B B B X X B X$, and $X B B X X B B B X X B B X$, where $B$ is one of the three basic amino acids (arginine, lysine or histidine) and $X$ is any of the other 17 natural amino acids [18-21].

Heparin-binding proteins such as fibroblast growth factors [22], antithrombin [23], hepatic and lipoprotein lipase [24,25], fibronectin [26], chemokines [27,28], and others have specific intrinsic affinity to bind strongly to heparin. Owing to their inherent strong binding affinity to heparin, HBPs can be readily purified to homogeneity using a single step by heparin-Sepharose affinity chromatography without the requirement of additional affinity tags. Based on the available knowledge of the amino acid sequence and structural determinants of heparin-binding affinity, in the present study, we have designed an overexpression vector that encodes a novel 34-amino acid heparin-binding (HB) peptide affinity tag fused to the nucleotide sequence of a non-heparin-binding target protein(s). The usefulness of the HB-tag in the single-step purification of different non-heparin-binding recombinant target proteins has been successfully demonstrated. In addition, polyclonal antibodies raised against the HB-tag have been shown to provide an avenue for the sensitive and specific detection of HB-fused recombinant proteins. In 
our opinion, the HB-tag is an immensely valuable affinity tag that can facilitate the simple, efficient, and reliable purification of recombinant proteins expressed in heterologous expression hosts.

\section{Materials and Methods}

Low-molecular-weight heparin was purchased from Sigma (St.Louis, MO). Heparin-Sepharose and GSH-Sepharose resins were purchased from GE Healthcare Bio-sciences (Pittsburgh, PA). All other general reagents were purchased from VWR Scientific (Radnor, PA). All antibodies were purchased from Genescript (Piscataway, NJ) using our specifications.

Solid-state synthesis of HB-peptide

Using FastMoc ${ }^{\circledR}$ chemistry, HB peptide was synthesized on a rink amide resin $\left(\mathrm{RAM}^{\mathrm{TM}}\right)$ mainly used for synthesis of peptide carboxamides with a modified protecting linker 4-((2,4dimethoxyphenyl)(Fmoc-amino)methyl) phenoxyacetic acid attached to the bead. The protecting group, 2,2,4,6,7-pentamethyl-dihydrobenzofuran-5-sulfonyl (PBF) present on the peptide that is bound to the resin was successfully cleaved with trifluoroacetic acid (TFA). Further, the synthetic peptide mixture along with other contaminants were loaded on to PRP3 reverse-phase HPLC column, and the impurities were removed using a linear gradient of water:acetonitrile. Purity of the peptide was confirmed by MALDI-TOF MS analysis.

\section{Construction of novel heparin-binding affinity fusion tag (HB-tag)}

The nucleotide sequence corresponding to HB tag was constructed by GeneArt, Life Technologies Inc. using the $E$. coli codon optimized gene synthesis facility. A thrombin cleavage site (-LVPRGS-) was added at the C-terminus of the affinity tag to allow the cleavage of the target protein from the tag. The amino acid sequence of the recombinant $H B$ peptide is shown below: MASKAQKAQAKQWKQAQKAQKAQAKQAKQAKQW.

Measurement of heparin-binding affinity of HB-peptide using isothermal titration calorimetry All isothermal titration calorimetric experiments were performed using iTC200 (MicroCal Inc., Northampton, MA) at $25^{\circ} \mathrm{C}$. The lyophilized HB-peptide, cleaved from its target protein, was dissolved in $10 \mathrm{mM}$ sodium phosphate buffer containing $100 \mathrm{mM} \mathrm{NaCl}$ at pH 7.2, resulting in a final concentration of $200 \mu \mathrm{M}$ HB-peptide, determined by absorbance spectroscopy at 280 $\mathrm{nm}$. Low-molecular-weight ( $3000 \mathrm{Da})$ heparin was dissolved in the same buffer to achieve a concentration of $2 \mathrm{mM}$. All samples were degassed under vacuum and equilibrated prior to the experiment. Heparin solution inside the syringe was titrated into the cell containing HB-peptide. Titration curves were analyzed using Origin Software supplied by MicroCal Inc. The raw ITC curves were best fitted to a one-binding-site model.

Cloning of C2A, S100A13, and CAlb3 into HB vector

The target proteins chosen (C2A domain $(\mathrm{MW} \sim 16 \mathrm{kDa})$ of mouse synaptotagmin-1 (C2A domain); mouse S100A13 (MW $12 \mathrm{kDa}$ ) and the C-terminal domain of Alb3 (MW 14 $\mathrm{kDa}$ ) (CAlb3) from Arabdopsis thaliana), to demonstrate the usefulness of the HB-tag, are not known to be heparin-binding proteins and do not have significant affinity to bind to heparinSepharose resin. Two expression vectors pET28a and pET22b from Novagen Inc. were used to generate the constructs consisting of the $\mathrm{HB}$ affinity tag. C2A gene was cloned into pET28a$\mathrm{HB}$ and the genes S100A13 and CAlb3 were cloned into pET22b-HB vectors.

Overexpression and purification of recombinant $H B$-fusion proteins 
The recombinant $\mathrm{pET}$-28a-HB-C2A fusion construct was used to transform the $\mathrm{BL} 21^{*} E$. coli expression host, whereas the $\mathrm{pET}-22 \mathrm{~b}-\mathrm{HB}$ fusion constructs were used to transform the BL21 (DE3) cells for S100A13 and Rosetta DE3 cells for CAlb3. Resulting transformants were grown in Luria-Bertani (LB) or Terrific (TB) medium containing kanamycin $(100 \mu \mathrm{g} / \mathrm{mL})$ for HBC2A or ampicillin $(100 \mu \mathrm{g} / \mathrm{mL})$ and chloramphenicol $(35 \mu \mathrm{g} / \mathrm{mL})$ for S100A13 and CAlb3, with shaking $(180 \mathrm{rpm})$ at $37^{\circ} \mathrm{C}$. The cells were later harvested by centrifugation at $4^{\circ} \mathrm{C}$ and 6000 $\mathrm{rpm}$ after $4 \mathrm{hr}$ of induction with $1 \mathrm{mM}$ isopropyl thio- $\beta$-D-galactoside (IPTG) and $\sim 5 \mathrm{~g}$ wet weight of cells was obtained from a liter of bacterial culture. Samples were taken prior to induction ("uninduced") as well as after the 4-hour induction prior to cell harvest ("induced"). Expression of the recombinant fusion protein was examined by resolving proteins on a 15\% SDS-PAGE and bands of interest were visualized by staining the gel with Coomassie Brilliant Blue-R250.

\section{Purification of HB-fusion proteins}

The HB-fusion proteins were purified using heparin-Sepharose affinity chromatography (6\% highly cross-linked spherical agarose) with a bed volume of $25 \mathrm{ml}$ and at a flow rate of 1 $\mathrm{ml} / \mathrm{min}$. The bacterial cells were lysed using the ultrasonicator (Microcon XL, Farmingdale, NY) at $4^{\circ} \mathrm{C}$ in $20 \mathrm{ml}$ of $10 \mathrm{mM}$ Tris- $\mathrm{HCl}$ buffer $\mathrm{pH}$. The cell lysate was subjected to high-speed centrifugation at 20,000 rpm for $30 \mathrm{~min}$. Using $10 \mathrm{mM}$ Tris buffers at $\mathrm{pH}$ 8, bound proteins were eluted in a stepwise gradient of $\mathrm{NaCl}(100-2000 \mathrm{mM})$. Fractions at various concentrations of $\mathrm{NaCl}$ gradient were collected and resolved on a SDS-PAGE. The fraction containing the HBfusion protein was dialyzed against $10 \mathrm{mM}$ Tris- $\mathrm{HCl}, 100 \mathrm{mM} \mathrm{NaCl}, \mathrm{pH}$. To demonstrate the ability of the HB-tag to be used under denaturing conditions, cells expressing HB-C2A were solubilized in $10 \mathrm{mM}$ Tris- $\mathrm{HCl}$ containing $8 \mathrm{M}$ urea, $\mathrm{pH}$. The suspension was further subjected to ultrasonication followed with centrifugation. All purification steps were performed similar to the ones used for native conditions.

\section{Cleavage and separation of the HB-peptide from target protein}

The dialyzed protein sample was concentrated using the Millipore centrifugal concentrator (MWCO $10 \mathrm{kDa}$ ). Concentration of the protein was determined both by absorbance at $280 \mathrm{~nm}$ using the molar extinction coefficient calculated from the amino acid sequence of the fusion proteins [29] and Bradford dye binding assay at $595 \mathrm{~nm}$. HB-C2A was subjected to thrombin cleavage (MP Biomedicals, Cleveland, $\mathrm{OH}$ ) at $37^{\circ} \mathrm{C}$ for 20 hours at a $1: 10$ molar ratio of protease to fusion protein. The thrombin-induced cleavage reaction was stopped by the addition of $0.2 \mathrm{mM}$ phenylmethylsulfonylfluoride (PMSF). Pure target protein (C2A) was eluted at $100 \mathrm{mM} \mathrm{NaCl}$ after passing the reaction mixture onto heparin-Sepharose column using the purification protocol stated above. The bound HB-peptide was eluted at high salt concentration $(500 \mathrm{mM})$. The other fusion proteins were cleaved in a similar fashion.

\section{Yield of C2A from glutathione-S-transferase(GST)- and HB-affinity tags}

The C2A gene was cloned into pGEX-4T1-GST expression vector between the BamHI and $X$ hol sites. The ligated product was transformed into E. coli BL21 (DE3) strain. GST-C2A was overexpressed and purified using the procedure standard for GST fusion proteins on GSHSepharose resin. This protocol includes washing bacterial proteins off the column with phosphate buffered saline (PBS), pH 7.2 and eluting GST-tagged proteins using $10 \mathrm{mM}$ reduced glutathione (GSH). GST-C2A then underwent thrombin cleavage for 20 hours at room temperature at a 1:5 molar ratio of protease to fusion protein. The concentration of pure C2A was determined by using its molar extinction coefficient of $12950 \mathrm{M}^{-1} \mathrm{~cm}^{-1}$ estimated by Gill and von Hippel [29]. 
Determination of the conformation of the purified recombinant C2A domain using Heteronuclear Single Quantum Coherence NMR

A 2-L culture of $\mathrm{HB}-\mathrm{C} 2 \mathrm{~A}$ was overexpressed in $\mathrm{M} 9$ medium with ${ }^{15} \mathrm{NH}_{4} \mathrm{Cl}(\mathrm{Cambridge}$ Isotope Laboratories Inc., Tewksbury, MA) as the sole source of nitrogen. Isotope-enriched HB$\mathrm{C} 2 \mathrm{~A}$ was purified using the standard protocol for HB-affinity tag. Thrombin cleavage and further purification using heparin-Sepharose yielded $320 \mu \mathrm{M} C 2 \mathrm{~A} .{ }^{1} \mathrm{H}-{ }^{15} \mathrm{~N}$ HSQC data were obtained for $\mathrm{C} 2 \mathrm{~A}$ at $500 \mathrm{MHz}$ on BrukerAvance spectrometer (Bruker Corp., Billerica, MS). The sample was in $10 \mathrm{mM}$ phosphate buffer, $100 \mathrm{mM} \mathrm{NaCl}$, pH $7.2\left(90 \% \mathrm{H}_{2} \mathrm{O}\right.$ and $\left.10 \% \mathrm{D}_{2} \mathrm{O}\right)$. Spectra were processed using Sparky software.

\section{Construction of polyclonal antibodies to detect HB-fusion proteins}

HB-antibodies (HB-Ab) were generated by Genescript, NJ, USA as per our specifications. The segment of the HB-peptide possessing the highest antigenicity was designed using the Optimum Antigen design program at the vendor site (http://www.genscript.com/PolyExpress.html). HB-Ab were raised in rabbits against the following peptide sequence, QKAQKAQAKQAKQAC. A cysteine residue was added to the Cterminal end of the peptide to couple to $\mathrm{N}$-terminus amino group of the carrier protein like thyroglobulin or Keyhole limpet hemocyanin (KLH) to the thiol group of the peptide using $m$ maleimidobenzoyl- $N$-hydroxysuccinimide ester (MBS) as a cross linking agent. The detailed protocol for the generation of HB-Ab can be obtained at the vendor website (http://www.genscript.com/PolyExpress.html).

\section{Immunoblotting assays of HB-fusion proteins}

In order to determine the specificity and efficacy of HB-Ab for HB-fusion proteins, crude protein samples were used in Western blotting. All samples from the purification of $\mathrm{HB}-\mathrm{C} 2 \mathrm{~A}$ were resolved on a 15\% SDS-PAGE gel and transferred onto a nitrocellulose membrane (VWR Scientific, Radnor, PA) for $2 \mathrm{hr}$. The membrane was blocked using $5 \%$ skim milk in $1 \mathrm{X}$ TBS-T (10 mM Tris, $100 \mathrm{mM} \mathrm{NaCl}, 0.05 \%$ Tween-20; $\mathrm{pH}$ 7.4) at room temperature for $30 \mathrm{~min}$. The blot was then incubated with anti-HB polyclonal antibodies in 1:2500 dilution overnight at room temperature. After the membrane was washed repeatedly in $1 X$ TBS-T* $(10 \mathrm{mM}$ Tris, $750 \mathrm{mM}$ $\mathrm{NaCl}, 0.05 \%$ Tween-20; $\mathrm{pH} 7.4$ ), it was incubated with anti-rabbit IgG conjugated with alkaline phosphatase in 1:2500 dilution for $2 \mathrm{hr}$ at room temperature. The protein band of interest on the membrane was detected using the NBT/BCIP (Nitro-blue tetrazolium/5-Bromo-4-chloro-3-indolyl phosphate) substrate after the membrane was washed extensively with $1 \mathrm{X}$ TBS- $\mathrm{T}^{*}$. The increase in salt strength was to prevent any nonspecific binding.

The limit of detection for pure HB-C2A was determined by using dot blotting assay. Starting with $1 \mu \mathrm{g} \mathrm{HB}-\mathrm{C} 2 \mathrm{~A}$, a serial dilution was performed until the lowest amount of $\mathrm{HB}-\mathrm{C} 2 \mathrm{~A}$ was $0.5 \mathrm{ng}$. Bovine serum albumin (BSA) was also used from $1 \mu \mathrm{g}$ to $10 \mathrm{ng}$. A $1-\mu \mathrm{L}$ sample was blotted onto the commercially provided nitrocellulose membrane directly and allowed to dry completely. Anti-HB antibodies and anti-rabbit lgG antibody were incubated with the blot for 2 $\mathrm{hr}$ each following the same Western blotting protocol using 1 X TBS-T (150 mM NaCl) without electro transferring. The limit of detection was further calculated by densitometric analysis using UN-scan-IT software (Silk Scientific Inc., Orem, UT).

The ability of HB-C2A to be detected in various cell lines, such as bacterial, mammalian, and yeast was determined by Western blotting. E. coli Rosetta (DE3) cells, Mus musculus NIH3 T3 cells, and Pichia pastoris KM71H cells (Life technologies Inc., Grand Island, NY) were lysed using ultrasonication. The cell lysate was subjected to high-speed centrifugation at 13,000 rpm. A total of $100 \mu \mathrm{g}$ of the respective host proteins, as determined by Bradford assay, was added to $10 \mu \mathrm{g} \mathrm{HB}-\mathrm{C} 2 \mathrm{~A}$ fusion protein. Samples were resolved on $15 \%$ SDS-PAGE gel and transferred onto a nitrocellulose membrane. The above protocol for Western blotting was followed for detecting HB-fusion proteins in other cell lines. 


\section{Results and Discussion}

Rationale used for the design of the HB-tag

The inspiration for the design of the HB-affinity tag primarily stems from the significant structural knowledge base that currently exists in the literature [30-34]. The consensus amino acid strings and the density of charges present in the heparin-binding pockets of wellcharacterized heparin-binding proteins were used as primary input(s) for the design of the HBtag. On the basis of an analysis of the amino acid sequences of proteins that are known to exhibit strong heparin-binding affinity, Cardin and Weintraub identified potential heparin-binding motifs [17]. Recently, using a computer string search algorithm, we identified consensus amino acid segments that are potentially involved in heparin-binding ability [35]. In addition, spatial orientation of the heparin-binding pockets from different HBPs were visually observed using PyMol visualization software (Schrodinger, LLC, Cambridge, MA). Our objective, for an optimal HB-peptide design, was to achieve an asymmetric distribution of positively charged amino acid residues in the three-dimensional structural models built for consensus HB strings. The optimization process required the repetitive use of lysine, alanine, and glutamine at specific locations in the HB-peptide. Two tryptophan residues were introduced at specific locations (W13 and W33) as a probe to monitor the purification and heparin-binding characteristics of the HB-peptide. Care was taken that the introduction of the tryptophan residues did not result in the loss of the heparin-binding property (data not shown).

\section{Heparin-binding properties of the HB-peptide}

A 19-amino acid, potential heparin-binding (HB) peptide was synthesized chemically (Fig.1A). To determine whether this peptide is the heparin-binding segment from FGF-1, isothermal titration calorimetry was performed to examine the affinity, stoichiometry and thermodynamics governing the binding of the peptide to heparin. Isothermogram of the HBpeptide and heparin interaction is hyperbolic and best fits to a one-site binding model (Fig. 1B). The affinity of the HB-peptide to heparin is observed to be $\sim 115 \mathrm{nM}$ suggesting that the designed HB-peptide indeed binds to heparin with much higher affinity similar to strong heparin binding proteins [13]. From this synthetic peptide, a recombinant HB-peptide was constructed as stated below, and the isothermogram of this peptide and heparin interaction is sigmoidal and best fits to a two-site binding model (supplemental figure S1). The apparent $\mathrm{K}_{\mathrm{d} 1}$ is $\sim 176 \mathrm{nM}$ and $\mathrm{K}_{\mathrm{d} 2}$ is $\sim 14 \mathrm{nM}$, suggesting a increase in binding affinity compared to that of the synthetic peptide.

\section{Construction of an overexpression vector containing the HB-affinity tag}

The strong affinity between the HB-peptide and heparin encouraged us to construct an expression vector that encodes a 34-amino acid HB-tag. The helical wheel plot of this peptide tag is shown in Fig. 2A. The positively charged amino acids in the helical wheel are aligned appropriately for binding to negatively charged sulfates on the heparin moiety.

The HB-tag was designed by expanding the amino acid sequence to 34 amino acids (from the 19 amino acid HB-peptide) by the inclusion of 15 additional amino acids. The additional 15 amino acids include multiple primary K-A-Q/ K-Q-A repeat units found in the HBpeptide. The rationale of including additional primary repeats was to further enhance the heparin-binding affinity of the HB-tag with the positively charged lysine residues projecting outward and fully accessible to bind to heparin. Two tryptophan residues were included in the $\mathrm{HB}$-tag design to monitor the purification of HB-fused target proteins by $280 \mathrm{~nm}$ absorbance and also to probe the conformational changes induced in the HB-tag upon binding to heparin. It was ensured that the spatial asymmetric distribution of the positively charged amino acid in the HBtag, for optimal heparin-binding, was still maintained (data not shown). 
Two versions of the $\mathrm{HB}$ expression vectors were constructed taking into consideration the use of different enzymatic cleavage methods available like thrombin and TEV proteases. $A$ cartoon of the vector map is shown in Fig. 2B (please refer to the supplemental figures S2-S4 for the actual nucleotide and amino acid sequences for the fusion constructs).

\section{Expression and purification of HB-fusion proteins}

HB-fused recombinant target proteins showed excellent expression upon induction with IPTG under similar growth conditions. The HB-fusion proteins were predominantly expressed as soluble proteins. This is evident from the strong band observed on the SDS-PAGE gels stained with Coomassie Brilliant Blue (Fig. 3A) and the apparent molecular weight of the proteins matched the theoretical weight.

The purification of the HB-fused target proteins, from the $E$. coli cell lysate, was achieved on heparin-Sepharose using a stepwise gradient of sodium chloride. The elution profile, monitored by $280 \mathrm{~nm}$ absorbance, showed a significant peak in the flow-through buffer (Fig. 3B, $10 \mathrm{mM}$ Tris buffer $(\mathrm{pH} 8))$. SDS-PAGE of the protein eluents in the flow-through did not reveal a prominent band corresponding to the HB-tagged target protein(s) (Fig. 3C). The proteins eluted in the flow-through were predominantly constituent $E$. coli impurities. SDS-PAGE of the fractions eluted in stepwise gradients of sodium chloride lower than $500 \mathrm{mM} \mathrm{NaCl}$ did not show a prominent band corresponding to HB-fused target proteins (Fig. 3C). The majority of the HBfused C2A domain eluted as a single band (> $95 \%$ pure) in $500 \mathrm{mM} \mathrm{NaCl}$. Increasing the salt gradient further up to $1200 \mathrm{mM}$ concentration did not elute any additional protein. However, interestingly, HB-CAlb3 and HB-S100A13 eluted predominantly as single bands at $1000 \mathrm{mM}$ (data not shown). The results discussed so far clearly suggest the following: 1. HB-fused target proteins bind strongly to heparin-Sepharose and elute as a pure protein at $500 \mathrm{mM} \mathrm{NaCl}$ or greater and 2. The elution of HB-fused S100A13 and HB-fused CAlb3 at higher concentrations of salt indicates that spatial distribution of positively charged residues in the HB-fused target proteins enhances their affinity to bind to heparin-Sepharose. It appears that HB-fused target proteins with higher $\mathrm{pl}$ values would have a higher tendency to elute at higher sodium chloride concentrations (> $500 \mathrm{mM} \mathrm{NaCl}$ ) because of the gross change in the positive amino acid residue content which might contribute to more interaction other than those formed by the $\mathrm{HB}$ tag alone. HB-CAlb3 and HB-S100A13 have pl values of 10.3 and 9.6, respectively (calculated from Expasy website). Similar observations, regarding the influence of target recombinant proteins, have been frequently reported for other peptide affinity tags, such as the polyhistidine tag $[36,37]$. It is important to mention that the affinity of the HB-fused protein is primarily driven by the affinity of the HB-tag to heparin-Sepharose because tag free C2A protein elutes from heparin-Sepharose column at sodium chloride concentrations at or lower than $100 \mathrm{mM}$ strength. It is pertinent to state that the elution profiles of the bacterial lysates, containing the HB-fused target proteins, did not show any discernable change in $10 \mathrm{mM}$ phosphate buffer (in the $\mathrm{pH}$ range of 6.5-8.0, data not shown). The final yield(s) of the recombinant proteins under both native and denaturing purification conditions is shown in Table 1. Under native purification conditions almost all of the protein present in the whole lysate was recovered from the heparinSepharose column but under denaturing conditions (in $8 \mathrm{M}$ urea), more than than $90 \%$ of the target protein was successfully recovered. This shows that the HB-tag can be efficiently used for purification of recombinant proteins under diverse experimental conditions.

Usefulness of the HB-tag to purify proteins in their denatured state(s)

It is well known that recombinant proteins, in several cases, are expressed as insoluble, inclusion bodies in heterologous hosts [38-40]. In most of these cases, it is challenging to recover proteins in their biologically active state. Attempts to recover recombinant proteins from inclusion bodies necessarily involve the use of chemical denaturants to dissolve the insoluble 
protein(s). However, purification of recombinant proteins, from their denatured states, poses a challenge because denatured protein affinity tags do not bind efficiently to their respective affinity resins. Under these circumstances, peptide tags, such as the polyhistidine tag, are better suited because they can bind to their target resin even in their denatured state(s) albeit with lower affinity. In this context, we examined the effectiveness of the HB-tag to purify recombinant proteins in their denatured states.

Urea is a widely used non-ionic protein denaturant [41-43]. Most proteins exist in a completely denatured state(s) in $8 \mathrm{M}$ urea. C2A domain of synaptotagmin has been previously shown to be completely denatured in $4 \mathrm{M}$ urea. HB-C2A can also be purified to homogeneity under denaturing conditions that include $8 \mathrm{M}$ urea (data not shown). We also examined the elution profile of HB-S100A13 on a heparin-Sepharose column, dissolved in $10 \mathrm{mM} \mathrm{Tris-HCl}$ (pH 8) containing $8 \mathrm{M}$ urea. Comparison of the elution profiles of the native and denatured HBS100A13 purifications significant difference (Fig. 4A \& 4B). HB-S100A13 mostly eluted in 1000 $\mathrm{mM} \mathrm{NaCl}$.

The elution profile of $6 \mathrm{M}$ guanidinium hydrochloride $(\mathrm{GdmHCl})$-treated $\mathrm{HB}-\mathrm{C} 2 \mathrm{~A}$ showed that the protein was mostly eluted in the flow-through (data not shown). These results suggest the HB-tag loses affinity to heparin-Sepharose in $6 \mathrm{M} \mathrm{GdmHCl}$. The loss of binding affinity is reasonable because $\mathrm{GdmHCl}$, being an ionic denaturant, likely disrupts the electrostatic interactions which are primarily responsible for the binding affinity between the HB-tag and the heparin-Sepharose resin. These results suggest that HB-fused recombinant target proteins can be successfully purified from their urea-denatured state(s).

\section{Cleavage of the affinity tag from the recombinant target protein}

As mentioned earlier, one important criterion of a good affinity tag is its resistance to degradation and amenability to be eliminated from the target protein by an enzymatic digestion. HB-fused target protein constructs independently contained a thrombin or TEV protease cleavage site. Overnight treatment of all the pure HB-fused target proteins with appropriate proteolytic enzymes (thrombin/TEV protease) resulted in the complete release of the HB-tag from the recombinant target protein (Fig. 5A and supplemental figures, S5 and S6). Importantly, no additional products, arising from non-specific cleavage of the HB-fused recombinant protein(s) were observed. This is corroborated by the ESI mass data (Fig. 5B and 5C), which only show two prominent peaks corresponding to the target protein (C2A domain, MW 16 $\mathrm{kDa})$ and the HB-tag (MW $4 \mathrm{kDa})$.

\section{Separation of the target recombinant proteins from the HB-tag}

The final purification of the target recombinant protein was performed by loading the mixture of the target protein and the HB-tag on heparin-Sepharose. The target recombinant protein eluted in the flow-through in $10 \mathrm{mM}$ Tris, $100 \mathrm{mM} \mathrm{NaCl}, \mathrm{pH}$. The separated HB-tag, bound to the heparin-Sepharose resin, only eluted in $500 \mathrm{mM} \mathrm{NaCl}$. One additional advantage with this chromatographic procedure is the successful elimination of enzyme thrombin from the cleaved mixture. It appears that thrombin is bound to the heparin-Sepharose resin, along with the HB tag, and therefore is not observed in the ESI-MS mass spectrum of the purified target protein. We had previously shown that thrombin has significantly strong affinity to bind to heparin and heparin-Sepharose resin [44]. In fact, the ability to eliminate thrombin (as an impurity) from the target recombinant proteins is an added advantage of the HB-tag based affinity chromatography. It should be mentioned that the final yield of the recombinant $\mathrm{C} 2 \mathrm{~A}$ domain, purified using the HB-tag, was quite similar to that obtained from using a GST-tag ( 16 $\mathrm{mg} /$ /iter of the bacterial culture). In addition, we would like to state that our attempts to purify recombinant CAlb3, using a polyhistidine tag or a GST tag, was unsuccessful owing to poor expression of the fusion protein and subsequent insurmountable difficulties encountered in the 
purification using the appropriate affinity resins (unpublished data). In this context, it is redeeming that we could successfully purify recombinant CAlb3 using the HB-tag.

\section{Conformation of the purified recombinant target protein(s)}

It is important to establish that the recombinant target protein(s) purified using the HBtag is in the biologically active conformation. Two-dimensional ${ }^{1} \mathrm{H}^{-15} \mathrm{~N}$ heteronuclear single quantum coherence spectroscopy (HSQC) is considered a "gold standard" for the determination of "nativity" of the backbone conformation of proteins $[45,46]$. Each peak in the ${ }^{1} \mathrm{H}-{ }^{15} \mathrm{~N} \mathrm{HSQC}$ spectrum corresponds to an amino acid in a particular protein backbone conformation. The proton, nitrogen, and carbon resonances in the C2A domain have been assigned and reported previously $[47,48]$. In this context, ${ }^{1} \mathrm{H}-{ }^{15} \mathrm{~N} \mathrm{HSQC}$ provides a reliable avenue to verify the backbone conformation of the recombinant $\mathrm{C} 2 \mathrm{~A}$ domain that was purified using the HB-tag. The ${ }^{1} \mathrm{H}-{ }^{15} \mathrm{~N} \mathrm{HSQC}$ spectrum of the recombinant $\mathrm{C} 2 \mathrm{~A}$, purified in this study, is well dispersed suggesting that the protein is in a well-folded conformation (Fig. 6). The overall spatial arrangement of peaks in the ${ }^{1} \mathrm{H}-{ }^{15} \mathrm{~N} \mathrm{HSQC}$ spectrum is similar to one published earlier [48], suggesting that the $\mathrm{C} 2 \mathrm{~A}$ domain (purified using the $\mathrm{HB}$-tag) is indeed in the native conformation.

\section{Immunoblotting of HB-fused recombinant target proteins}

Polyclonal antibodies were developed against the HB-tag ( $\mathrm{Hb}-\mathrm{Ab})$ to specifically detect HB-fused recombinant target proteins in crude cell lysates. The sensitivity of HB-Ab was examined by dot blot assay using pure $\mathrm{HB}$-fused $\mathrm{C} 2 \mathrm{~A}$ domain. It was observed that $\mathrm{HB}-\mathrm{Ab}$ could detect the HB-fused protein(s) at concentration levels as low as 10 nanograms (Fig. 7A \& 7B).

Further, the specificity of HB-Ab was verified by Western blotting of the bacterial, yeast, and mammalian cell lysate, which were individually spiked with $10 \mu \mathrm{g}$ of HB-C2A. The results of Western blotting clearly show the specific detection of a $\sim 20 \mathrm{kDa}$ band corresponding to the HB-fused C2A domain in all the crude cell lysates used (Fig. 7C and 7D). These results suggest that the polyclonal antibodies raised against the HB-tag are very sensitive and can specifically detect HB-fused recombinant target protein(s) in different crude cell lysates.

\section{Conclusions}

1) In this study, we have designed and constructed a novel expression vector containing a heparin-binding (HB) tag for the purification of recombinant target proteins overexpressed in $E$. coli.

2) HB tag shows a very high affinity toward the heparin-Sepharose matrix and can be used to purify recombinant target proteins using single-step affinity chromatography.

3) HB-fused recombinant target proteins can also purified under denaturing conditions.

4) Polyclonal antibodies raised against the HB-tag are sensitive and can specifically detect HB-fused recombinant proteins in different types of crude cell lysates. 
In our opinion, the HB-tag provides a highly reliable option for the simple, rapid, and cost-effective production and purification of recombinant or therapeutic proteins on laboratory and industrial scales. Work is currently in progress to investigate whether the HB-tag can be used to prevent recombinant proteins from being expressed as inclusion bodies.

\section{Acknowledgements}

This work was supported in part by grants from the National Institutes of Health [NCRR COBRE Grant 1 P20 RR15569 (TKSK), P30 GM103450 (TKSK), the Department of Energy (Grant DEFG02-01ER15161 (RH and TKSK), National Science Foundation and the Arkansas Biosciences Institute (TKSK).

\section{Contributions}

TKSK conceptualized the research described in this manuscript. SJ, JM and AK participated in the design and construction of the different HB-tag clones, RL \& AD involved in the preparation of synthetic peptide and also contributed for characterization of HB synthetic peptide. JM and SJ were involved in the execution of the experiments. JM, SJ, DM, RH and TKSK analyzed and interpreted the data. JM, SJ and TKSK wrote the manuscript.

Authors claim no conflict of interest. 


\section{References:}

[1] J. Arnau, C. Lauritzen, G. Petersen, J. Pedersen, Current strategies for the use of affinity tags and tag removal for the purification of recombinant proteins. Protein Express. Purif. 48 (2006) 1-13.

[2] N. Ferrer-Miralles, J. Corchero, P. Kumar, J. Cedano, K. Gupta, A. Villaverde, E. Vazquez, Biological activities of histidine-rich peptides; merging biotechnology and nanomedicine. Microb. Cell Fact. 10 (2011) 1-5.

[3] J. Lichty, J. Malecki, H. Agnew, D. Michelson-Horowitz, S. Tan, Comparison of affinity tags for protein purification. Protein Express. Purif. 41 (2005) 98-105.

[4] N. Park, J. Ryu, S. Jang, H. Lee, Metal ion affinity purification of proteins by genetically incorporating metal-chelating amino acids. Tetrahedron 68 (2012) 4649-4654.

[5] I. Hunt, From gene to protein: a review of new and enabling technologies for multiparallel protein expression. Protein Express. Purif. 40 (2005) 1-22.

[6] D. Esposito, D. Chatterjee, Enhancement of soluble protein expression through the use of fusion tags. Curr. Opin. Biotechnol. 17 (2006) 353-358.

[7] K. Terpe, Overview of tag protein fusions: from molecular and biochemical fundamentals to commercial systems. Appl. Microbiol. Biotechnol. 60 (2003) 523-533.

[8] M. Martinez-Ceron, A. Targovnik, N. Urtasun, O. Cascone, M. Miranda, S. Camperi, Recombinant protein purification using complementary peptides as affinity tags. New Biotechnol. 29 (2012) 206-210.

[9] S. Batra, N. Sahi, K. Mikulcik, H. Shockley, C. Turner, Z. Laux, V. Badwaik, E. Conte, D. Rajalingam, Efficient and inexpensive method for purification of heparin binding proteins. Journal of Chromatography B. 879 (2011) 2437-2442.

[10] G. Launay, R. Salza, D. Multedo, N. Thierry-Mieg, S. Ricard-Blum, MatrixDB, the extracellular matrix interaction database: updated content, a new navigator and expanded functionalities. Nucleic Acids Res. 43 (2015) D321-D327.

on the solubility of MBP fusion proteins. J. Struct. Funct. Genomics 2002, 2, 83-92.

[11] J. Esko, R. Linhardt, Proteins that Bind Sulfated Glycosaminoglycans. In Essentials of Glycobiology. 2nd ed. (2009); A. Varki, R. Cummings, J. Esko et al., Ed.; Cold Spring Harbor Laboratory Press: New York, chapter 35.

[12] J. Fang, Y. Dong, N. Salamat-Miller, C. Middaugh, DB-PABP: a database of polyanionbinding proteins. Nucleic Acids Res. 36 (2008) D303-D306.

[13] F. Peysselon, S. Ricard-Blum, Heparin-protein interactions: from affinity and kinetics to biological roles. Application to an interaction network regulating angiogenesis. Matrix Biol. 35 (2014) 73-81.

[14] S. Someya, M. Kakuta, M. Morita, K. Sumikoshi, W. Cao, Z. Ge, O. Hirose, S. Nakamura, T. Terada, K. Shimizu, Prediction of carbohydrate-binding proteins from sequences using support vector machines. Adv Bioinformatics 2010 (2010), 1-9.

[15] D. Small, V. Nurcombe, G. Reed, H. Clarris, R. Moir, K. Beyreuther, C. Masters, A heparin-binding domain in the amyloid protein precursor of Alzheimer's disease is involved in the regulation of neurite outgrowth. J. Neurosci. 14 (1994), 2117-2127.

[16] Y. Zhang, N. Jiang, B. Jia, Z. Chang, Y. Zhang, X. Wei, J. Zhou, H. Wang, X. Zhao, S. Yu, M. Song, Z. Tu, H. Lu, J. Yin, M. Wahlgren, Q. Chen, A comparative study on the heparinbinding proteomes of Toxoplasma gondii and Plasmodium falciparum. Proteomics 14 (2014), 1737-1745.

[17] A. Cardin, H. Weintraub, Molecular modeling of protein-glycosaminoglycan interactions. Arteriosclerosis (Dallas) 9 (1989) 21-32.

[18] M. Sobel, D. Soler, J. Kermode, R. Harris, Localization and characterization of a heparin binding domain peptide of human von Willebrand factor. J. Biol. Chem. 267 (1992), 8857-8862. 
[19] H. Margalit, N. Fischer, S. Ben-Sasson, Comparative analysis of structurally defined heparin binding sequences reveals a distinct spatial distribution of basic residues. J. Biol. Chem. 268 (1993), 19228-19231.

[20] J. Fromm, R. Hileman, E. Caldwell, J. Weiler, R. Linhardt, Pattern and spacing of basic amino acids in heparin binding sites. Arch. Biochem. Biophys. 343 (1997), 92-100.

[21] M. Torrent, M. Nogues, D. Andreu, E. Boix, The "CPC clip motif": a conserved structural signature for heparin binding proteins. PLoS One 7 (2012), e42692.

[22] R. Raman, V. Sasisekharan, R. Sasisekharan, Structural insights into biological roles of protein-glycosaminoglycan interactions. Chem. Biol. 12 (2005), 267-277.

[23] R. Tyler-Cross, M. Sobel, D. Marques, R. Harris, Heparin-binding domain peptides of antithrombin III: analysis by isothermal titration calorimetry and circular dichroism spectroscopy. Protein Science 3 (1994), 620-627.

[24] W. Yu, J. Hill, Mapping the heparin binding domain of human hepatic lipase. Biochem. Biophys. Res. Commun. 343 (2006), 659-665.

[25] H. Wong, M. Schotz, The lipase gene family. J. Lipid. Res. 43 (2002), 993-999.

[26] M. Mitsi, K. Forsten-Williams, M. Gopalakrishnan, M. Nugent, A catalytic role of heparin in the extracellular matrix. J. Biol. Chem. 283 (2008), 34796-34807.

[27] J. De Paz, E. Moseman, C. Noti, L. Polito, U. Von Andrian, P. Seeberger, Profiling heparin-chemokine interactions using synthetic tools. ACS Chem. Biol. 2 (2007), 735-744. [28] F. Culley, E. Fadlon, A. Kirchem, T. Williams, P. Jose, J. Pease, Proteoglycans are potent modulators of the biological responses of eosinophils to chemokines. Eur. J. Immunol. 33 (2003), 1302-1310.

[29] S. Gill, P. Von Hippel, Calculation of protein extinction coefficients from amino acid sequence data. Anal. Biochem. 182 (1989) 319-326.

[30] J. Fromm, R. Hileman, E. Caldwell, J. Weiler, R. Linhardt, Pattern and spacing of basic amino acids in heparin binding sites. Arch. Biochem. Biophys. 343 (1997) 92-100.

[31] N. Gandhi, R. Mancera, The structure of glycosaminoglycans and their interactions with proteins. Chem. Biol. Drug Des. 72 (2008) 455-482.

[32] I. Capila, R. Linhardt, Heparin-protein interactions. Angew. Chem. Int. Ed. 41 (2002) 390-412.

[33] H. Margalit, N. Fischer, S. Ben-Sasson, Comparative analysisof structurally defined heparin binding sequences reveals a distinct spatial distribution of basic residues. J. Biol. Chem. 268 (1993) 19228-19231.

[34] A. Beenken, M. Mohammadi, The FGF family: biology, pathophysiology, and therapy. Nat. Rev. Drug. Discov. 8 (2009) 235-253.

[35] C. Dempewolf, J. Morris, M. Chopra, S. Jayanthi, T. Kumar, W. Li, Identification of consensus glycosaminoglycan binding strings in proteins, 2013 International Conference on Information Science and Applications (ICISA), pp.1-5, 24-26 June 2013.

[36] D. Westra, G. Welling, D. Koedijk, A. Scheffer, T. Theb, S. Welling-Wester, Immobilised metal-ion affinity chromatography purification of histidine-tagged recombinant proteins: a wash step with a low concentration of EDTA. J. Chromat. B 760 (2001) 129-136.

[37] K. Franken, H. Hiemstra, K. Van Meijgaarden, Y. Subronto, J. Den Hartigh, T. Ottenhoff, J. Drijfhout, Purification of his-tagged proteins by immobilized chelate affinity chromatography: the benefits from the use of organic solven. Prot. Express. Purif. 18 (2000) 95-99.

[38] S. Mondal, D. Shet, C. Prasanna, H. Atreya, High yield expression of proteins in E. coli for NMR studies. Adv. Biosci. Biotech. 4 (2013) 751-767.

[39] A. Pina, C. Lowe, A. Roque, Challenges and opportunities in the purification of recombinant tagged proteins. Biotech. Adv. 32 (2014) 366-381.

[40] E. García-Fruitós, E. Vázquez, C. Díez-Gil, J. Corchero, J. Seras-Franzoso, I. Ratera, J. Veciana, A. Villaverde, Bacterial inclusion bodies: making gold from waste. Trends Biotechnol. 30 (2012) 65-70. 
[41] U. Boonyuen, K. Promnares, S. Junkree, N. Day, M. Imwong, Efficient in vitro refolding and functional characterization of recombinant human liver carboxylesterase (CES1) expressed in E. coli. Prot. Express. Purif. 107 (2015) 68-75.

[42] I. Mačinković, M. Abughrena, I. Mrkica, M. Grozdanović, R. Prodanović, M. GavrovićJankulović, Employment of colorimetric enzyme assay for monitoring expression and solubility of GST fusion proteins targeted to inclusion bodies. J. Biotechnol. 168 (2013) 506-510.,

[43] G. Wang, J. Han, S. Wang, P. Li, Expression and purification of recombinant human bone morphogenetic protein-7 in Escherichia coli. Prep. Biochem. Biotechnol. 44 (2014) 16-25.

[44] D. Rajalingam, K. Kathir, K. Ananthamurthy, P. Adams, T. Kumar, A method for the prevention of thrombin-induced degradation of recombinant proteins. Anal. Biochem. 375 (2008) 361-363.

[45] B. Meyer, T. Peters, NMR spectroscopy techniques for screening and identifying ligand binding to protein receptors. Angew. Chem. Int. Ed. 42 (2003) 864-890.

[46] V. Pomin, J. Sharp, X. Li, L. Wang, J. Prestegard, Characterization of glycosaminoglycans by $15 \mathrm{~N}$ NMR spectroscopy and in vivo isotopic labeling. Anal. Chem. 82 (2010) 4078-4088.

[47] D. Rajalingam, T. Kumar, C. Yu, The C2A domain of synaptotagmin exhibits a high binding affinity for copper: implications in the formation of the multiprotein FGF release complex. Biochemistry 44 (2005) 14431-14442.

[48] D. Rajalingam, I. Graziani, I. Prudovsky, C. Yu, T. Kumar, Relevance of partially structured states in the non-classical secretion of acidic fibroblast growth factor. Biochemistry 46 (2007) 9225-9238. 
Table 1: Purification yield(s) of recombinant C2A domain

\begin{tabular}{|c|c|c|c|c|c|}
\hline & Fraction type & $\begin{array}{c}\text { Total } \\
\text { protein } \\
(\mathbf{m g})\end{array}$ & $\begin{array}{l}\text { Recombinant } \\
\text { C2A protein } \\
\text { (mg) }\end{array}$ & $\begin{array}{c}\% \\
\text { Recovery }\end{array}$ & $\begin{array}{c}\% \\
\text { Purity }\end{array}$ \\
\hline \multirow{4}{*}{$\begin{array}{c}\text { Purification } \\
\text { under } \\
\text { native } \\
\text { condition }\end{array}$} & Whole lysate & 150 & 15 & 100.00 & 10 \\
\hline & $500 \mathrm{mM} \mathrm{NaCl}$ fraction & 15 & 15 & 100.00 & 100 \\
\hline & $\begin{array}{c}\text { After desalting \& } \\
\text { concentration }\end{array}$ & 13 & 13 & 86.67 & 100 \\
\hline & $\begin{array}{c}\text { Thrombin cleavage } \& \text { 2nd } \\
\text { pass }\end{array}$ & 10 & 10 & 66.67 & 100 \\
\hline \multirow{4}{*}{$\begin{array}{c}\text { Purification } \\
\text { under } \\
\text { denaturing } \\
\text { (8M urea) } \\
\text { condition }\end{array}$} & Whole lysate & 125 & 13 & 86.67 & 10.4 \\
\hline & $500 \mathrm{mM} \mathrm{NaCl}$ fraction & 12 & 12 & 80.00 & 100 \\
\hline & $\begin{array}{c}\text { After desalting \& } \\
\text { concentration }\end{array}$ & 9 & 9 & 60.00 & 100 \\
\hline & $\begin{array}{c}\text { Thrombin cleavage } \& \text { 2nd } \\
\text { pass }\end{array}$ & 8 & 8 & 53.33 & 100 \\
\hline
\end{tabular}

Purification was performed using 0.5 gram wet weight of E.coli cells containing the overexpressed recombinant HBC2A protein 


\section{Legends to Figures:}

Fig. 1. Heparin-binding affinity of the synthetic HB-peptide. (A) Amino acid sequence of the synthetic HB-peptide. (B) Isothermogram of HB synthetic peptide interacting with heparin. Upper panel represents the raw data showing the injection and the heat evolved. Lower panel shows the best fit of the data to the one-binding site model (Origin Lab, Northampton, MA).

Fig. 2. Sequence and cloning information of recombinant HB-peptide. (A) Amino acid sequence and helical wheel plot of recombinant HB-affinity tag. The positively charged residues are distributed on one side of the HB-tag. (B) Cartoon representation of the recombinant expression vector maps containing the HB-tag fused recombinant target protein(s). C2A domain was cloned into pET-28a-HB vector. S100A13 and CAlb3 were cloned into pET-22b$\mathrm{HB}$ vector.

Fig. 3. Overexpression and purification of recombinant $H B$-fused $C 2 A$ domain. (A) Coomassie Brilliant Blue stained SDS-PAGE of the overexpression of HB-C2A: Protein molecular weight marker (lane 1) uninduced E. coli pellet (lane 2); IPTG-induced E. coli cell culture (lane 3). Lane 3 shows that HB-C2A is expressed with significantly high yield, as indicated by an arrow at approximately $20 \mathrm{kDa}$. (B) Elution profile of HB-C2A on heparin-Sepharose (bed volume $\sim 25$ $\mathrm{ml}$ ) using a stepwise gradient of sodium chloride in $10 \mathrm{mM}$ Tris- $\mathrm{HCl}, \mathrm{pH}$ 8. The volume of the clear E.coli lysate (harvested from a 1-liter culture) was loaded onto a $25 \mathrm{ml}$ heparin-Sepharose column. The flow rate of the eluent was set at $1 \mathrm{ml} / \mathrm{min}$. (C) Coomassie Brilliant Blue stained SDS-PAGE of the fractions obtained using heparin-Sepharose: Protein molecular weight marker (lane 1); soluble fraction (lane 2) and insoluble fraction (lane 3) obtained from the 1-liter culture; $0 \mathrm{mM} \mathrm{NaCl}$ fraction (lane 4); $100 \mathrm{mM} \mathrm{NaCl}$ fraction (lane 5); $350 \mathrm{mM} \mathrm{NaCl}$ fraction (lane 6); 500 $\mathrm{mM} \mathrm{NaCl}$ fraction (lane 7). The arrows in Panels $A \& C$ represent the band corresponding to the recombinant $\mathrm{HB}-\mathrm{C} 2 \mathrm{~A}$. Lane 7 shows $\mathrm{HB}-\mathrm{C} 2 \mathrm{~A}$ purified to homogeneity in good yield (20 $\mathrm{mg} /$ liter of the culture).

Fig. 4. Purification HB-fused $S 100 A 13$ under native and denatured conditions. (A) Coomassie Brilliant Blue stained SDS-PAGE of HB-S100A13 purified under native conditions: Protein molecular weight marker (lane 1); insoluble (lane 2) and soluble (lane 3) fractions obtained from a 1-liter culture; $0 \mathrm{mM} \mathrm{NaCl}$ fraction (lane 4); $100 \mathrm{mM} \mathrm{NaCl}$ fraction (lane 5); $350 \mathrm{mM} \mathrm{NaCl}$ fraction (lane 6) and $1000 \mathrm{mM} \mathrm{NaCl}$ (lane 7) fraction. A $500 \mathrm{mM} \mathrm{NaCl}$ gradient, used prior to the $1000 \mathrm{mM} \mathrm{NaCl}$ gradient, did not produce a discernable peak on the chromatogram. (B) Coomassie Brilliant Blue stained SDS-PAGE of HB-S100A13 under $8 \mathrm{M}$ urea denaturing conditions: Protein molecular weight marker (lane 1); insoluble (lane 2) and soluble (lane 3) fractions obtained from a 1-liter culture; $0 \mathrm{mM} \mathrm{NaCl}$ (lane 4) fraction; $100 \mathrm{mM} \mathrm{NaCl}$ (lane 5) fraction; $350 \mathrm{mM} \mathrm{NaCl}$ (lane 6) fraction; $500 \mathrm{mM} \mathrm{NaCl}$ (lane 7) fraction and the $1000 \mathrm{mM} \mathrm{NaCl}$ (lane 8). HB-S100A13 was successfully purified to homogeneity under denaturing conditions. A step-dialysis was subsequently employed for removal of urea to obtain the refolded target recombinant protein.

Fig. 5. Separation of target protein from the HB-tag. (A) Coomassie Brilliant Blue stained SDSPAGE of HB-C2A after thrombin treatment: Protein molecular weight marker (lane 1); HB-C2A (lane 2); thrombin-cleaved HB-C2A (lane 3). MALDI-TOF spectra of C2A (B) and the HB-tag (C) after thrombin cleavage and separation on heparin-Sepharose.

Fig. 6. Backbone conformation of $\mathrm{C} 2 \mathrm{~A}$ after separation from HB-affinity tag. C2A protein purified on heparin-Sepharose with HB-affinity tag showed an intact folded conformation as seen by the spatial arrangement of the peaks in the ${ }^{1} \mathrm{H}-{ }^{15} \mathrm{~N} \mathrm{HSQC}$ spectrum. 
Fig. 7. Detection of HB-fusion protein using polyclonal antibodies. (A) Limit of detection of HBC2A was determined by dot blot assay: The dot blots are labeled as Circle 1 to $8.1 \mu \mathrm{gg}$ (circle 1); 500 ng (circle 2); 100 ng (circle 3); 50 ng (circle 4); 10 ng (circle 5); 5 ng (circle 6); 1 ng (circle 7); $0.5 \mathrm{ng}$ (circle 8); Circles 9-13 are BSA: $1 \mu \mathrm{gg}$ (circle 9); $500 \mathrm{ng}$ (circle 10); $100 \mathrm{ng}$ (circle 11); $50 \mathrm{ng}$ (circle 12); $10 \mathrm{ng}$ (circle 13). The limit of detection for the HB-fused protein was on the nanogram scale, which is extremely advantageous for detection of proteins, which are expressed in low yields. (B) Bar graph depicting the desitometric scan of the dot blot with concentration of HB-C2A and percentage average pixel on Y-axis. (C) Coomassie Brilliant Blue stained SDS-PAGE and (D) Western blot of spiked HB-C2A in different cell lines: pure HB-C2A as positive control (lane 1); E.coli cell lysate spiked with HB-C2A (lane 2); NIH-3T3 mammalian cell lysate spiked with HB-C2A (lane 3); Yeast cell lysate spiked with HB-C2A (lane 4); pure C2A used as negative control (lane 5). Lanes 2-4 show that the fusion protein is detected in all the cell lysates, whereas in lane 5, C2A alone was not detected.

Table. 1. Purification table showing the fold purity and \% recovery of C2A fused to HB-affinity tag under native and denatured conditions. 
A WASKAQKAQAKQAKQAQKA

B

Time (min)

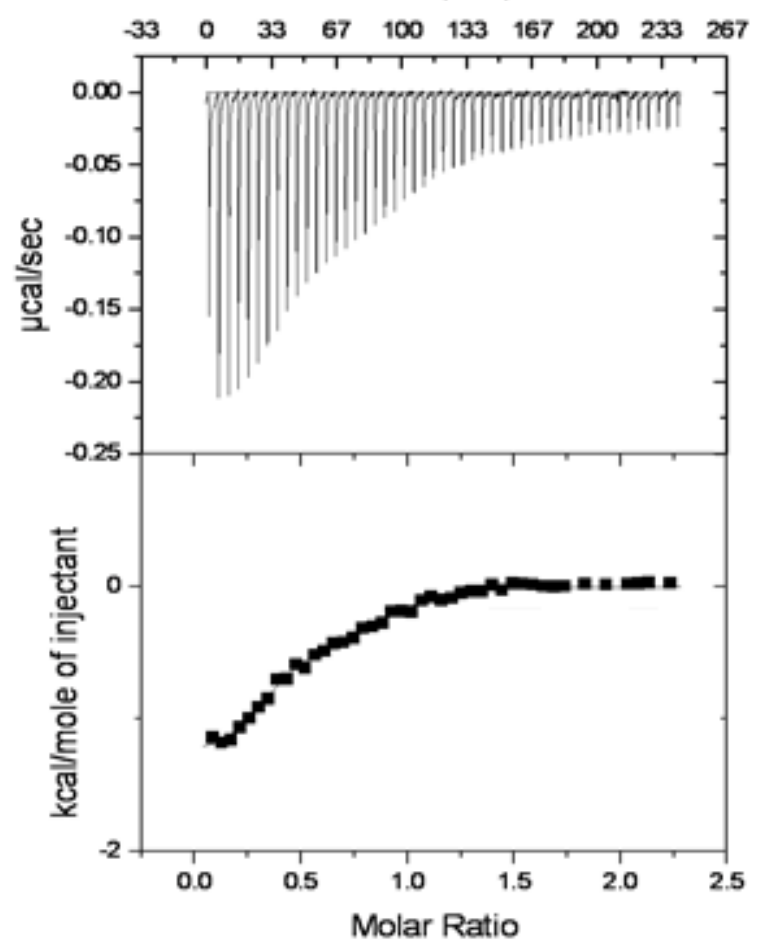

Fig. 1. 
A

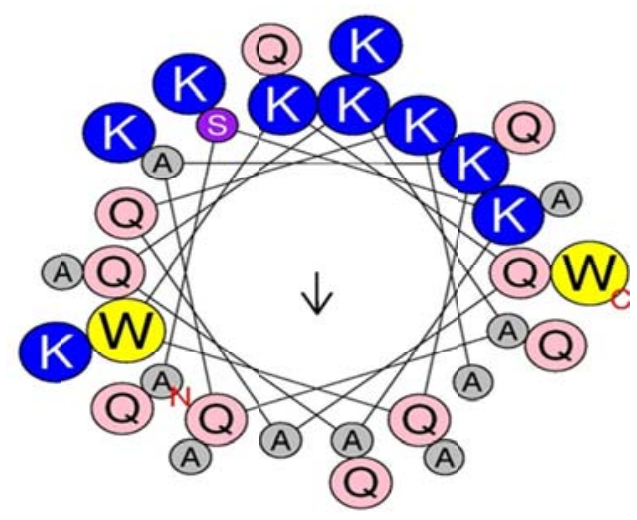

\section{ASKAQKAQAKQWKQAQKAQKAQAKQAKQAKQW}

B
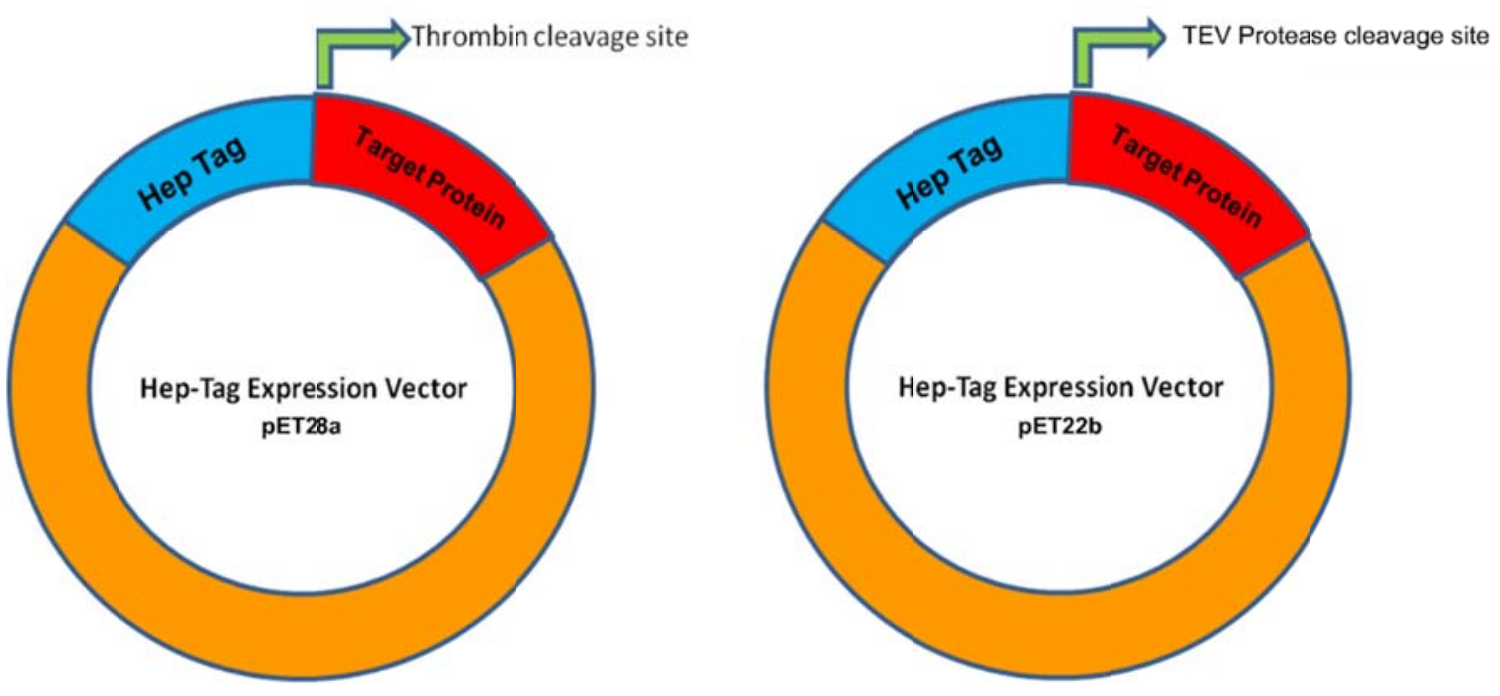

Fig. 2 

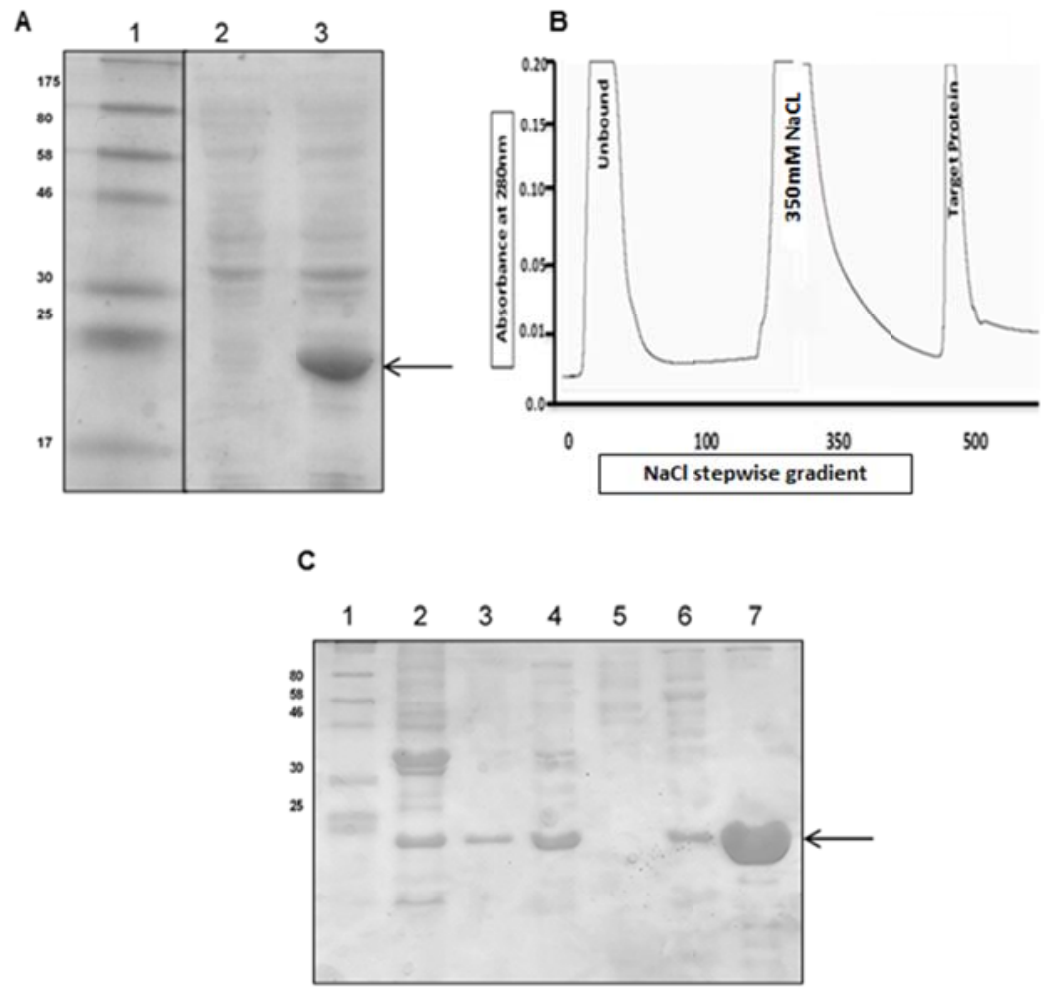

Fig. 3 
A

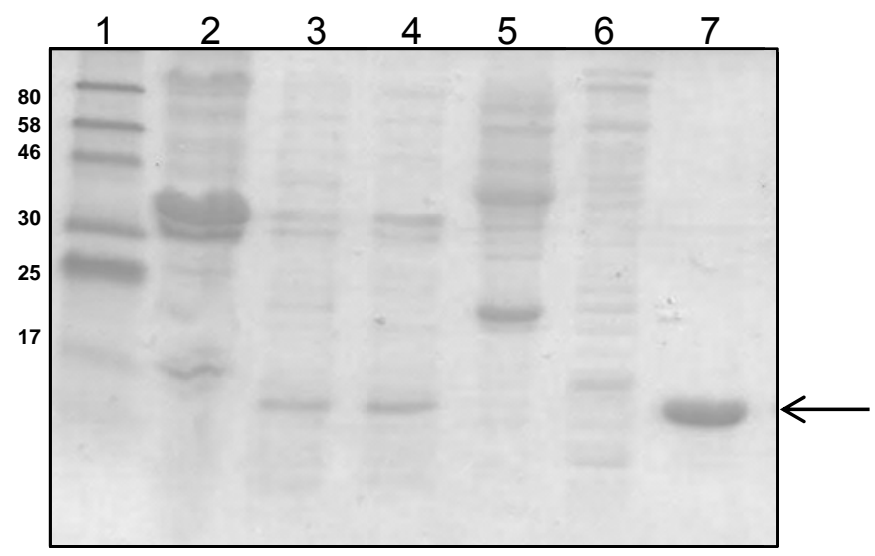

B

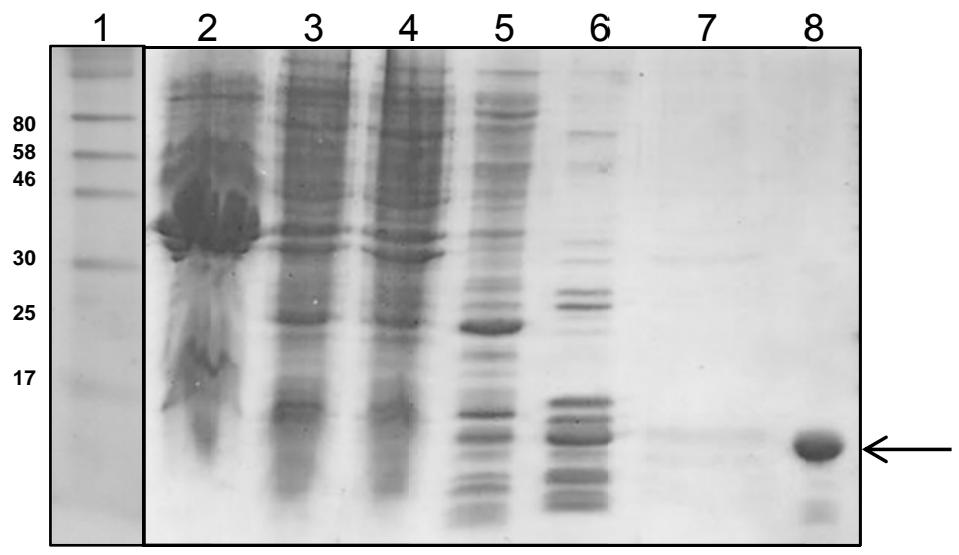

Fig. 4 
A

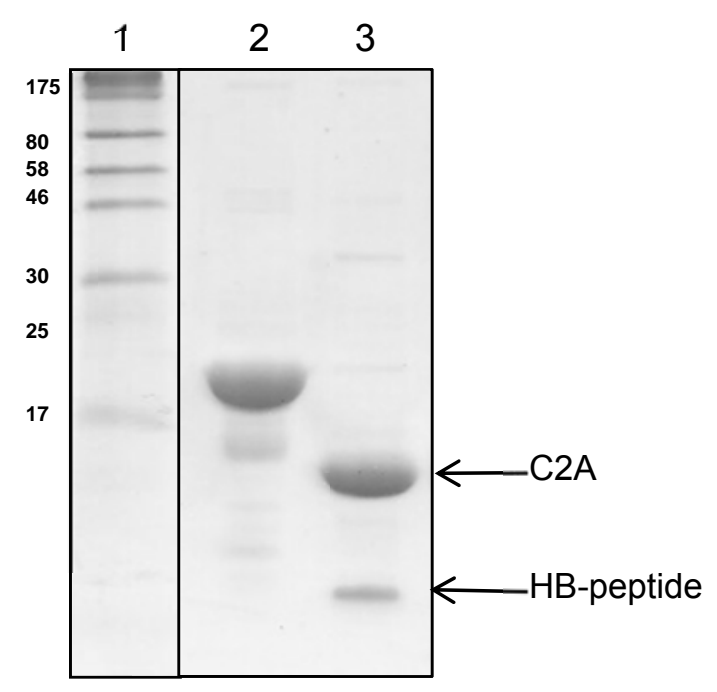

B

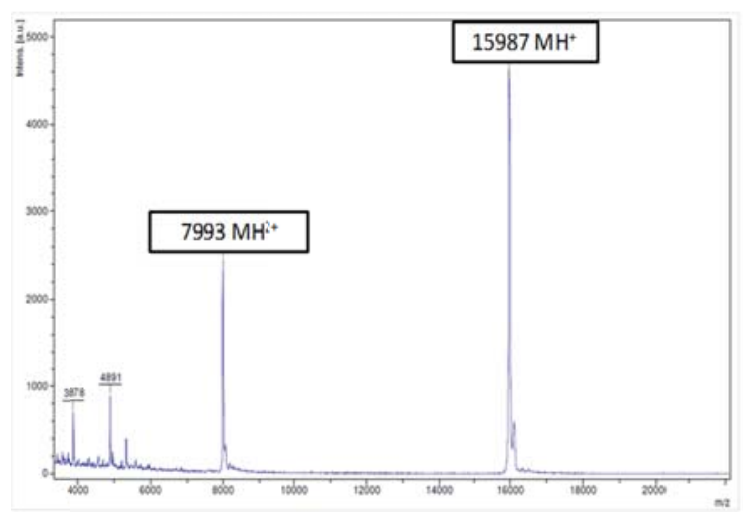

C

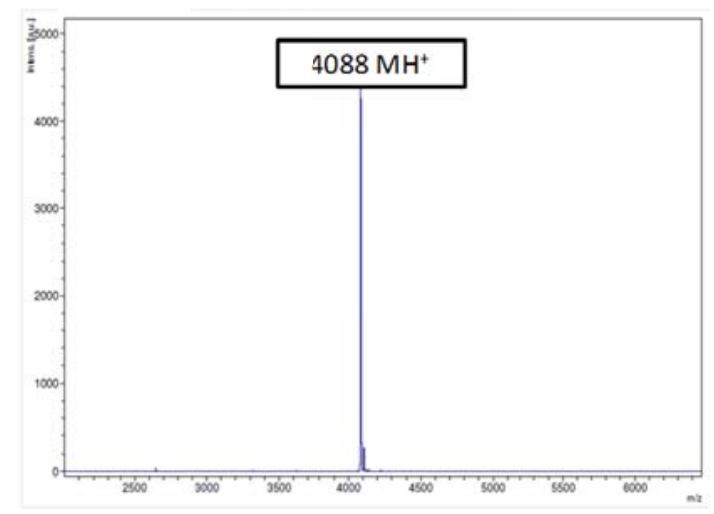

Fig. 5

22 


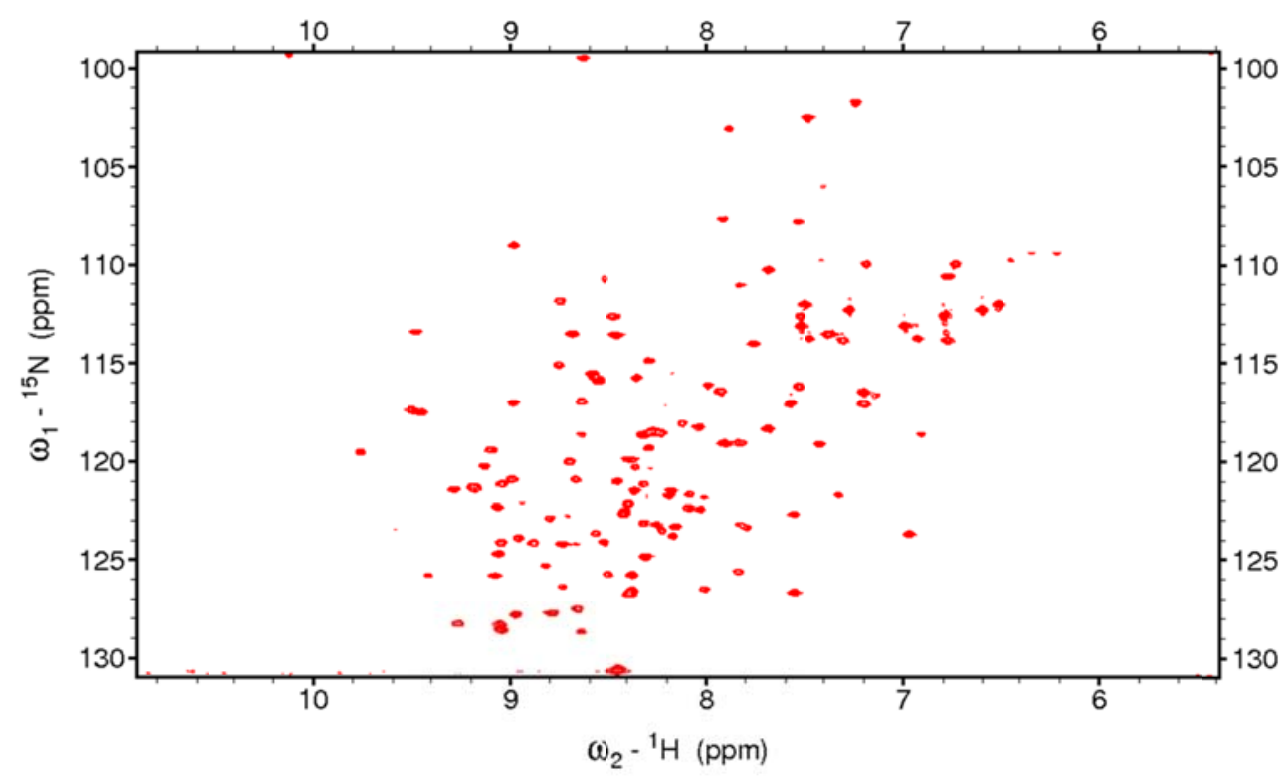

Fig. 6 

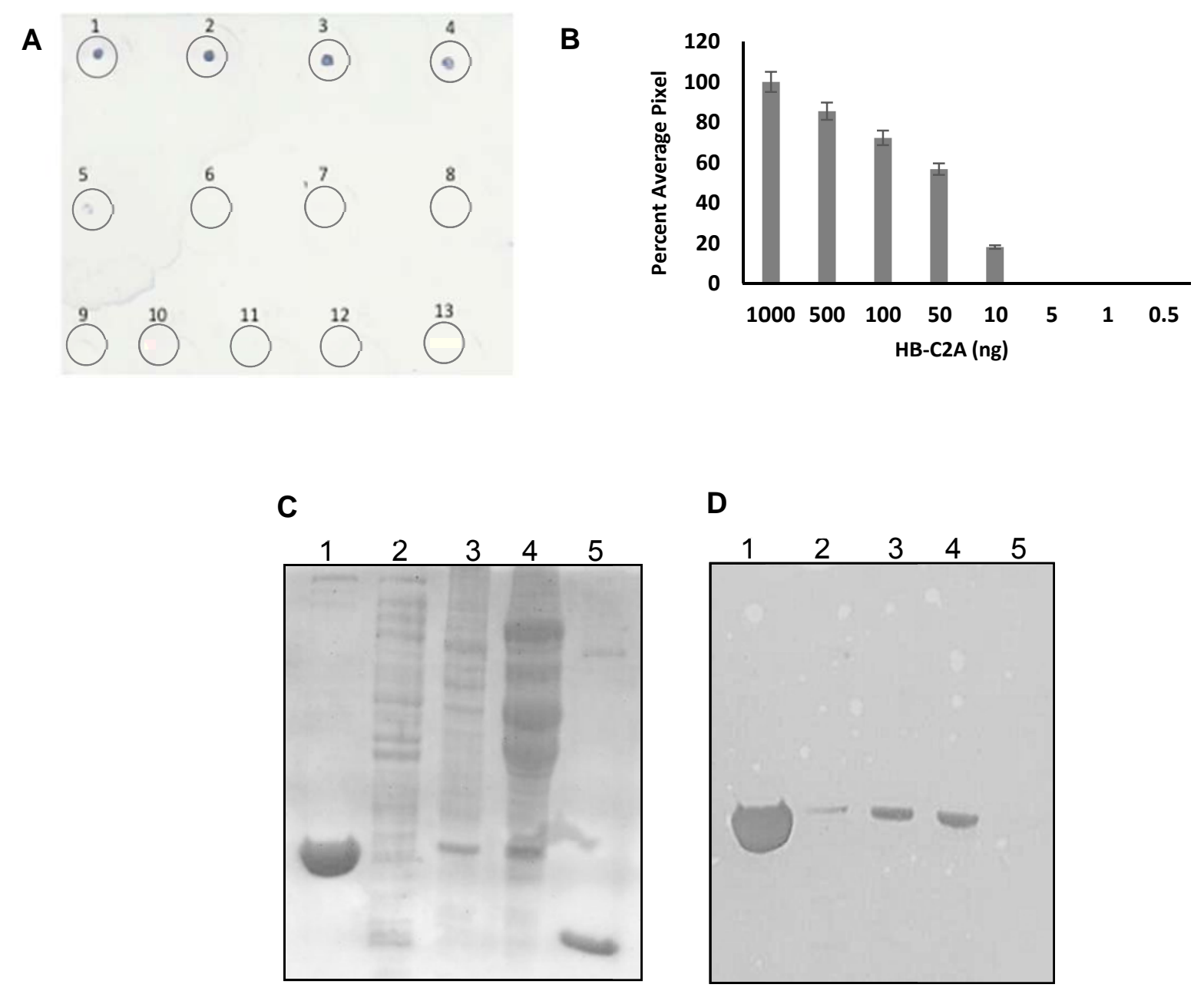

D

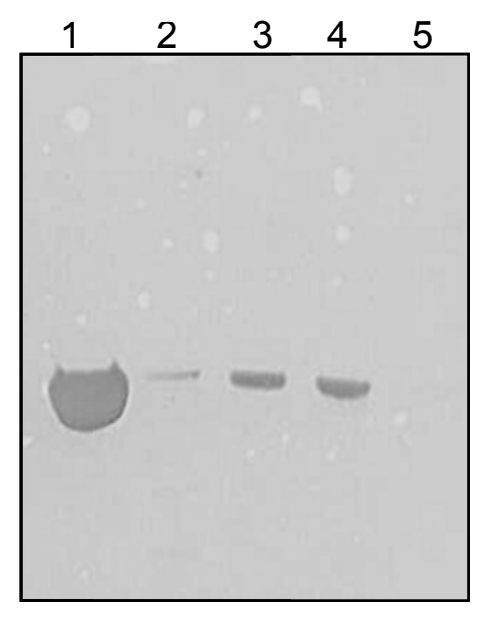

Fig. 7 